\title{
Effect on Mouse Aortic Endothelial Cells (MAEC) and Human Umbilical Vein Endothelial Cells (HUVEC) of Xanthohumol Flavonoid Isolated from Hops (Humulus Lupulus L.)
}

\author{
Md. Mahfujul Haque Haidary ${ }^{1 *}$, Md. Serajul Islam² \\ ${ }^{1}$ Wuxi School of Medicine, P. R. China \\ ${ }^{2}$ State key Laboratory, Jiangnan University, P. R. China
}

*Corresponding author: Md. Mahfujul Haque Haidary, Wuxi School of Medicine, Jiangnan University, 1800 Lihu Ave, Wuxi, China

\begin{abstract}
ARTICLE INFO
Received: 幽 November 11, 2019

Published: November 22, 2019

Citation: Md. Mahfujul Haque Haidary, Md. Serajul Islam. Effect on Mouse Aortic Endothelial Cells (MAEC) and Human Umbilical Vein Endothelial Cells (HUVEC) of Xanthohumol Flavonoid Isolated from Hops (Humulus Lupulus L.). Biomed J Sci \& Tech Res 23(2)-2019. BJSTR. MS.ID.003860.
\end{abstract}

Keywords: Xanthohumol; MAEC cell; HUVEC cell; Cell culture; Calcium Imaging

\section{ABSTRACT}

Aim: Xanthohumol is one of the principle flavonoids isolated from hops (Humulus lupulus L.), a medicinal plant for a long history and shows anti-cancer and anti-angiogenic activities. This study will investigate the effect of drug on isolated thoracic aorta and the cultured Human Umbilical Vein Endothelial Cells.

Methods: Mouse aortic endothelial cell isolated, cultured and the Human umbilical vein endothelial cells were cultured by using the cell passaging technique to keep cells alive and growing under cultured conditions for extended periods of time. The calcium imaging had done on both cells to observe the frequency of spontaneously occurring $\mathrm{Ca}^{+2}$ sparks in cells before adding the drug and after adding the drug with a concentration of 1.5nM to 5nM on HUVEC cell and endothelial aortic cell.

Results: The cell growth under cultured conditions were insured and the primary cell culture of MAEC was done according to the conditions and showed a good cell growth in the medium. HUVEC cell passaging was done according to the protocol. Xanthohumol reduced the frequency of $\mathrm{Ca}^{+2}$ sparks and waves after using the drug on HUVEC cells with no significant on endothelial aortic cells.

Conclusion: Xanthohumol's effect on MAEC cells and HUVEC cells give a further study guideline for the endothelial cell's role in the cardiovascular protection by using this drug. Potential preventive effects on the development of cardiovascular disease, treatment of endothelial cells with Xanthohumol leads to find out the phosphorylation level and the further apoptosis protein expression.

\section{Introduction}

Xanthohumol is a natural product found in the female inflorescences of Humulus lupulus. In recent years, there has been a growing interest on phenolic compounds, which contribute to prevention of various degenerative diseases, such as cancer and cardiovascular diseases. Different investigation divulged that herbs are mostly used in the treatment of hypertension in different regions. Che et al. [1] who reported Flavonoids were beneficial effects on cardiovascular diseases by improving endothelial function. More people become senior in age and the world population crosses 8 billion, the number of deaths from cardiovascular diseases. Numerous studies have reported that Xanthohumol protects cell from oxidative DNA damage and oxidative stress in a dosedependent manner Xanthohumol (XN) required a chalcone structure and prenyl group for the cell's activity [2]. Researchers found that XN negatively interferes with endothelial cell growth, migration, invasion and the ability to form a network of tubular- 
like structures [3]. The biological effect, may be in a smaller extent, could be caused by different types of flavonoids [4]. As a prenylated chalcone are among the phenolic compounds which have received the most importance in recent years [5]. Xanthohumol, an antioxidant, is found at high concentrations in hop cones (Humulus lupulus L.) and is a common ingredient of beer [6]. It's a prenylated flavonoid of the chalcone type, produced in the lupulin glands of the hop cones [7]. This compound has a range of interesting biological properties that may have therapeutic utility and contribute to the further study for cardiovascular system mechanism of XN. However, the pharmacological properties of Xanthohumol were not evaluated until 90's, including antioxidant, antibacterial, anti-inflammatory, antifungal, antiviral, and anti-plasmodial activity [6].

Hemodynamic blood circulation is one of the important physiological attributes that regulate vascular tone. In many cases, a key early signal in this flow induced vascular dilation is $\mathrm{Ca}^{+2}$ influx in endothelial cells such as HUVEC and MAEC in response to flow $[8,9]$. In vascular endothelial cells, flow may activate P2X4 purinoceptors, which are $\mathrm{Ca}^{+2}$ - permeable channels, resulting in vascular dilation. In general, natural phenolic substances have health-protective criteria, which are likely regarded to their effect on vasorelaxant activities. Herbal medicines have a long history in the controlling of hypertension by reducing blood pressure with slight side effects. Hops used in beer production are a source of polyphenols such as xanthohumol (XN), and its metabolites isoxanthohumol (IXN) and phytoestrogen 8-prenylnaringenin (8PN). The advantage of pharmacological properties of Xanthohumols was not accentuated until the beginning of 2000s but it showed antioxidant, anti-inflammatory activity [5]. Hops have been used as a medicinal plant for a long time. Hops (Humulus lupulus L.) widely used throughout the world in the brewing industry. Xanthohumol (Xn; 30-[3,3-dimethylallyl]-20,40,4-trihydroxy-60-methoxychalcone), the prenylated flavonoid with $1 \%$ of dry weight in hops, can be isolated from the female inflorescences [10]. The aims of this study to find out Xanthohumol's effect on different cells and further considered the targeted cell lines based on drugs effect will be observed. These cell lines the Mouse Aortic Endothelial Cell and Human Umbilical Vein Endothelial Cells were chosen. The further experiment the herbal drug may be cause the vasorelaxant effect on the aortic endothelial cell and may be useful in the prevention of hypertension.

\section{Material and Methods}

\section{Chemicals and Reagents}

Xanthohumol was purchased from the Med Chem Express, USA. Xanthohumol, Type IA collagen from Collagenase of clostridium histolyticum (CAS:9001-12-1,SIGMA ADRICH), Heparin Sodium (CAS\#9041-08-1BR,store at $4{ }^{\circ} \mathrm{C}$ and lot :B30S9R70907,DMEM (Dulbecco's Modified Eagle Medium) from Thermo fisher Scientific Ref.(C11995500BT), ECM(Endothelial Cell Medium), Catalogue No. 1001 ,storage at $2-8{ }^{\circ} \mathrm{C}$ from Scientific Research Laboratories was purchased and 0.25\% Trypsin-EDTA, ref.no. 25200-056, from gibco laboratories was bought for continuous cell culture process and also for the cell's enzymic digestion. Fluo-4,AM, Molecular weight of 1096.95,lot no. 1948082 purchased from Thermo Fisher scientific for using in the Calcium Imaging experiment. All other chemicals used were analytical reagent grade.

\section{Sample}

All animal experiments were performed in accordance with the laboratory animal guidelines and with the approval of the animal experimentation ethics committee, Jiangnan University. Mouse aortic endothelial cells were isolated from C57BL/6 mice and used for experiments without any passage [11]. The human umbilical vein endothelial cells were cultured by using cell passageway to further growth in the culture medium.

\section{Method of Primary Cell Culture with Appropriate Reagents}

Two milligram Heparin Sodium was taken into $10 \mathrm{ml}$ tube and mixed with $10 \mathrm{ml}$ Phosphate-buffered saline (PBS, pH 7.4). Then used for the washing of the aortic cell. In Addition, added 6mg of Type IA collagen was taken into another $10 \mathrm{ml}$ tube and further added $3 \mathrm{ml}$ of Heparin Sodium (PBS). After that Primary mouse aortic endothelial cells were isolated from C57BL/6 mice [12]. After being anesthetized, by cutting the abdomen small intestines were dissected out and the aortic bed containing blood vessels along the small intestines was carefully removed. Then the endothelial aortic portion was cut into small pieces and in a small petridish the prepared collagen and Heparin sodium (PBS pH 7.4) [13]. The mixture placed in the hot water bath at $37{ }^{\circ} \mathrm{C}$ for 20 minutes for incubate. After incubation, added 2ml DMEM (Dulbecco's Modified Eagle Medium) in the incubated tube and centrifuged at $3000 \mathrm{rpm}$ for $5 \mathrm{~min}$ utes. After centrifuge, removed the non-adherent cell softly and the pelleted cells were re-suspended in Endothelial Cell Medium ( $2 \mathrm{ml}$ ) with $1 \mathrm{ml}$ penicillin streptomycin cell growth supplement and cultured in a flask at $37{ }^{\circ} \mathrm{C}$ with $5 \% \mathrm{CO}_{2}$. Non-adherent cells were removed after 2 hours. The adherent endothelial cells were cultured in $\mathrm{EGM}$ at $37^{\circ} \mathrm{C}$ with $5 \% \mathrm{CO}_{2}$ for 2 days $\mathrm{He}$ et al. [11]

\section{Cell Passaging for Continuous Cell Growth of Mouse Aortic Endothelial Cell in the Culture Medium}

For experimental procedure, the mouse aortic endothelial cells were transferred through the cell passaging way technique to observe more growth and for later experiment of calcium imaging. After 2-3 days, collect the cell cultured medium and by using $0.25 \%$ Trypsin-EDTA for continuous cell culture the medium was changed to a new culture plate for further experiment.

\section{HUVEC Cell Passaging Culture Method}

The previous medium was removed before the cell passaging procedure. The flask was cleaned adequately by using phosphatebuffered saline three times. Then after washing each time made sure of the removing of PBS from the cultured flask. In addition, for continuous cell growth used the enzymatic $0.25 \%$ Trypsin-EDTA of $3 \mathrm{ml}$ in the flask and placed in the incubator at $37^{\circ} \mathrm{C}$ for 5 minutes. 
After that added ECM with $1 \mathrm{ml}$ penicillin streptomycin cell growth supplement was putted into $5 \mathrm{ml}$ flask and mixed properly. After mixing, transferred $10 \mathrm{ml}$ into the centrifuge tube at $1200 \mathrm{rpm}$ for 5 minutes. After centrifugation removed the liquids in the disposal flask and nonadherent cells were removed. Again, added $1 \mathrm{ml}$ $(1000 \mu \mathrm{l})$ of endothelial cell medium in the $10 \mathrm{ml}$ tube and mixed properly. Then take $700 \mu \mathrm{l}$ of that mixing amount to a new larger culture flask and added $5300 \mu$ l of that endothelial cell medium with that penicillin streptomycin cell growth supplement to it and in another small flask added rest of the mixer amount's $300 \mu \mathrm{l}$ and again added $2200 \mu \mathrm{l}$ of endothelial cell medium with that penicillin streptomycin cell growth supplement for further growth of cell in the medium. The adherent HUVEC cells were cultured in ECM at 37 ${ }^{\circ} \mathrm{C}$ with $5 \% \mathrm{CO}_{2}$ for 2 days [14].

\section{$\mathrm{Ca}^{+2}$ Concentration Measurement in HUVEC and MAEC Cells}

HUVEC and MAEC cells were grown on $20 \mathrm{~mm}$ glass bottom cell culture dishes (Catalogue.No.: 801001) is a polystyrene and nonpyrogenic sterile. After loading cells were washed with phosphate buffer saline (PBS) for 3-5 times and used for calcium imaging experiment. HUVEC and MAEC cultured cells were loaded with $1 \mu \mathrm{l}$ of fluorescent dye (Fluo-4/AM) which is cell permeant, desiccate, protect from light, $0.02 \%(15 \mu \mathrm{l})$ of pluronic Eagle's Medium F-127 (Thermo fisher scientific,lot:1948082) and DMSO (Dimethyl Sulfoxide) $65 \mu \mathrm{l}$ for 0.5 hours in the dark at $37{ }^{\circ} \mathrm{C}$ in normal physiological saline solution(NPSS)containing $35 \mathrm{~mm}$ dishes. Nazıroğlu, Blum [15] who reported that Xanthohumol drug applied in both cell types to observe the calcium-influx experiments, the calcium concentration change in response to the drug was measured in different concentration of the drug ranging from 1.5 to $5 \mathrm{nM}$. The drug was added to the mentioned solutions by pipette and remained in the solution until the end of the experiments [15]. NPSS contained the following: $140 \mathrm{mmol} / \mathrm{L} \mathrm{NaCl}, 5 \mathrm{mmol} / \mathrm{L} \mathrm{KCl}, 5 \mathrm{mmol} / \mathrm{L} \mathrm{KCl}, 1$ $\mathrm{mmol} / \mathrm{L} \mathrm{CaCl}_{2}, 1 \mathrm{mmol} / \mathrm{L} \mathrm{MgCl}_{2}, 10 \mathrm{mmol} / \mathrm{L}$ glucose, and $5 \mathrm{mmol} / \mathrm{L}$ HEPES, $\mathrm{P}^{\mathrm{H}} 7.4$ [16]. Fluo-4 fluorescence was measured by using laser excitation at $488 \mathrm{~nm}$ of a confocal microscope (LSM 880 model, ZEISS, Germany). Fluorescence images for cell cytoplasm were collected simultaneously. Circular-shaped regions of interest (ROI) were placed inside the cytoplasmic area of cells. The fluorescence values were calculated after background subtraction. Bleaching correction was carried out, when the baseline was not stable. The relative fluorescent unit $(\mathrm{F}(\mathrm{t}) / \mathrm{F}(0))$ values were calculated for each cell. Each experimental procedure was repeated several times, but only one series of experiments is reported for each case. Prism 3 (Graph Pad Software, Inc., San Diego, CA) software was used for data analysis [15].

\section{Statistical Analysis}

All data are expressed as the mean \pm SD comparisons by using one-way analysis of variance (ANOVA) and for multiple group comparisons ( $\mathrm{P}<0.0001)$ and Bartlett's test for equal variances $(\mathrm{P}<0.0001)$; respectively, using Graph Pad PRISM software [17]. Further, t-test had done for ensuring the $95 \%$ confidence interval and the F-test to compare variances. Measured parameters (magnitude and Tau of calcium transients, the number of spontaneous calcium release events of calcium transients and Ica) were generally normalized relative to values measured under control conditions, in the absence of the drug to eliminate variability from cell to cell.

\section{Results}

\section{Proper Morphology of HUVEC and MAEC for Further Cell Generation}

The cell culture provides appropriate cell generation through the culture and by using cell passaging technique. The HUVEC and MAEC cell isolation and preventing from degradation by regular basis cell culture ensure the morphology of the cell [18].

\section{Long Term Cultures of HUVEC and MAEC Cell Culture Difference}

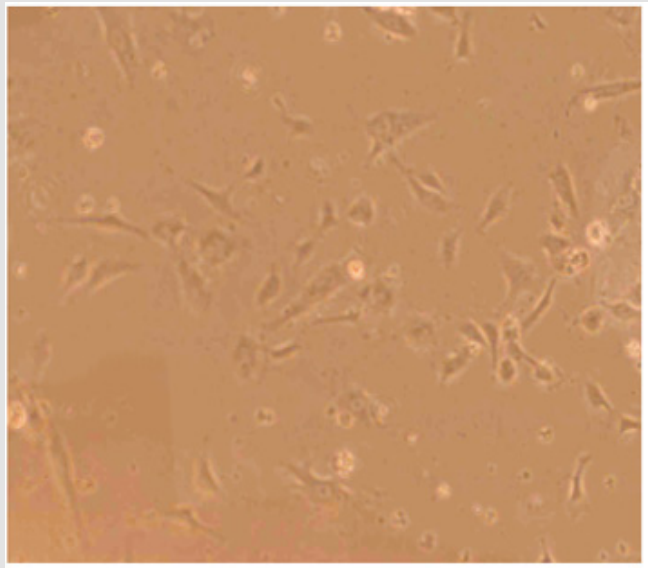

(A)

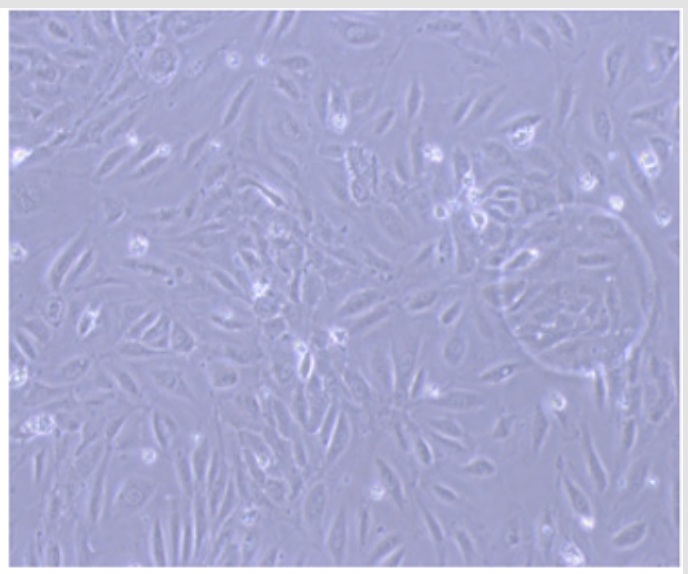

(B)

Figure 1: Electron microscopic observation of the HUVEC cell culture given large number of cell proliferation and growth in the medium. The regular basis cell culture ensured the cell viability. The cell culture and isolation was performed for several times. (A) high resolution and (B) slightly lower resolution. 
The cell culture for longer period of HUVEC and MAEC cells were suitable for further experimental method to apply. From the HUVEC cell culture usually got maximum cell proliferation and growth in the medium. The regular basis cell culture ensured the cell viability. The HUVEC cell had greater cell viability than the MAEC cell, while performed the both cell culture. Another significant difference between the two different cell cultures ensures that the isolation technique from the tissue may cause some different cell viability after the incubation period [19]. The cell culture provided large samples for further calcium imaging technique are revealed in Figure 1.

\section{Proliferation and Survival of HUVEC and MAEC Cell}

The proliferation rates in culture of HUVEC cells and MAEC cells were compared are shown in Figure 1\&2. In proliferation medium
(DMEM with 10\% FBS, 1\% penicillin/streptomycin), the HUVEC cells proliferate significantly faster than the MAEC cell group. There was no significant difference in proliferation rates between HUVEC cells and MAEC cells [19].

\section{Effect of Xanthohumol (XN) in HUVEC and MAEC Cell as an Antioxidant}

XN shown to exert antioxidant activity (Figure 2), which could be used a cardiac preventive compound. The $\mathrm{Ca}^{+2}$ transients' activity was evaluated of XN by using HUVEC and MAEC cells proliferation, viability and cell functions. Calcium imaging test showed that XN inhibits cell proliferation/viability more efficiently in the MAEC cell than previous finding by Negrão et al. [5].

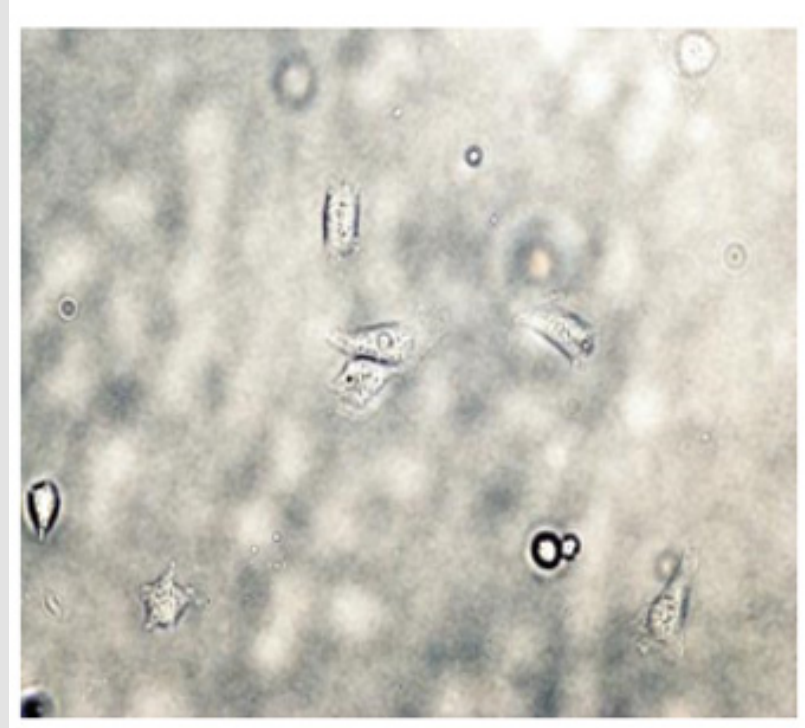

(A)

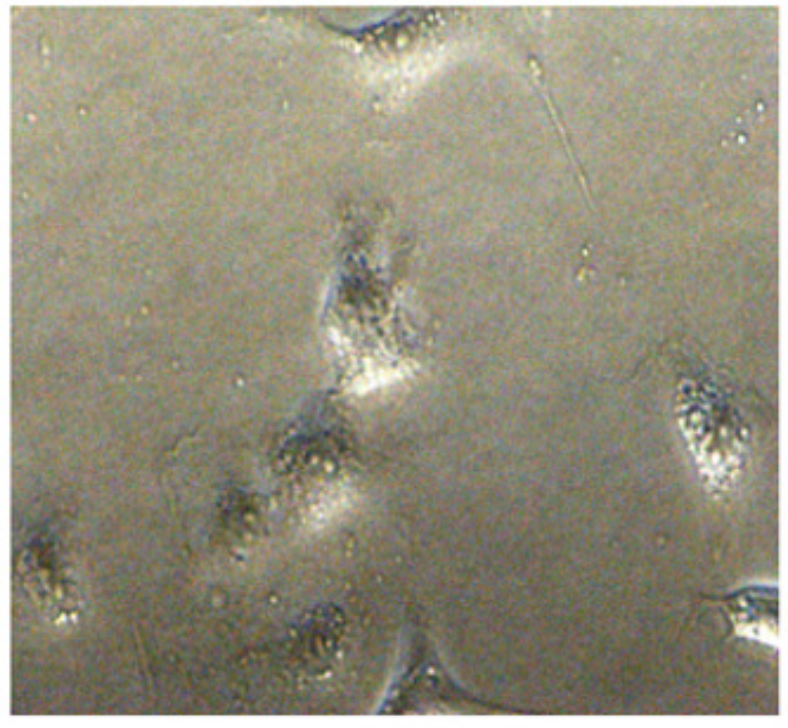

(B)

Figure 2: Electron microscopic observation of the MAEC cell culture given lesser number of cell proliferation and growth in the medium.

A. Moderate resolution and

B. Higher resolution.

\section{Xanthohumol Stimulates Apoptosis of HUVEC Cells In Vitro}

Reduced growth is the net result of reduced proliferation and increased cell death. The mice heart invasion assay revealed a strong selective effect on the morphology of the HUVEC cells, nuclear pyknosis and formation of vacuoles suggested signs of cell death. Therefore, the effect of xanthohumol on apoptosis of HUVEC was investigated (Figure 3). HUVEC cell was treated with xanthohumol within different concentrations. On treatment with xanthohumol, HUVEC cell line showed sensitivity to the drug. To summarize, xanthohumol seemed to increase apoptosis of HUVEC cell in vitro [20].

\section{Intracellular Localization of Xanthohumol}

The facility of fluorescence of xanthohumol 488nM to determine its uptake (green trace) of fluorescence images recorded in HUVEC and MAEC cell for 3 minutes both before and after addition 1.5 to $5 \mathrm{nM}$ concentration of the drug (3,5 and 10 $\mu \mathrm{l})$. After 3 minutes, the cellular fluorescence intensity produced by $488 \mathrm{nM}$ xanthohumol was captured respectively (Figure $3 \& 4$ ). Confocal imaging of pre incubated cells confirmed the dose-dependent uptake [8]. 

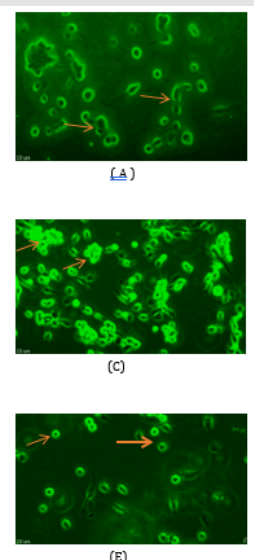

(E)
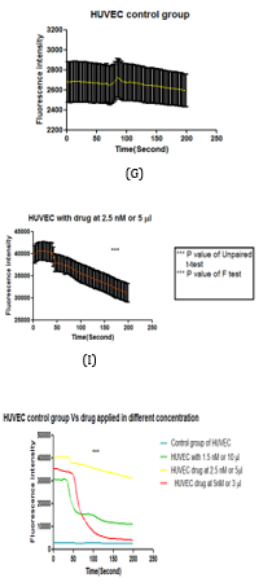

$(\mathrm{k})$
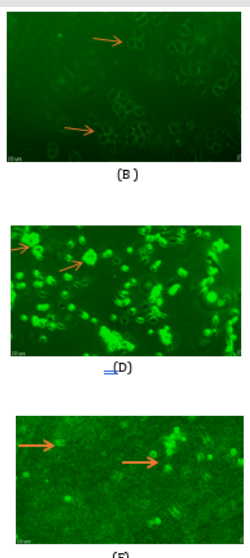

$\stackrel{(F)}{ }$
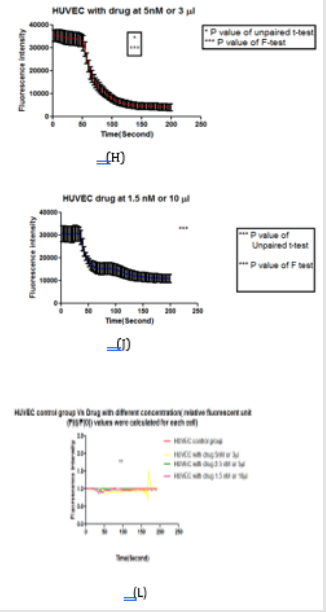

Figure 3: The effect of xanthohumol on apoptosis of HUVEC was investigated. HUVEC cell was treated with xanthohumol within different concentrations $(1.5 \mathrm{nM}$ to $5 \mathrm{nM})$. On treatment with xanthohumol, HUVEC cell line showed sensitivity to the drug.

A. Represents the HUVEC cell before adding drug;

B. Represents the drug after adding drug at $5 \mathrm{nM}$ concentration;

C. Before adding drug;

D. Image in the confocal microscope at $2.5 \mathrm{nM}$ concentration of the drug;

E. The HUVEC cell before adding drug;

F. Drug after adding drug at $1.5 \mathrm{nM}$ concentration for $10 \mu \mathrm{l}$ volume;

G. HUVEC control group without drug at constant rate, graph showed by using PRISM software; showed with error bars and connecting line;

H. Drug at $5 \mathrm{nM}$ concentration on HUVEC cell showed sudden decrease of calcium waves and frequencies after 50 seconds later in the graph; showed with error bars and connecting line; unpaired t-test had done, P value $(0.0260), P$ value summary $\left(^{*}\right)$ and means are significantly different $(\mathrm{P}<0.05)$, difference between means $(0.02737 \pm 0.01215), 95 \%$ confidence interval $(0.003550$ to 0.05118 , and $\mathrm{R}$ squared $(0.03812)$, F-test $(\mathrm{P}<0.0001)$, P value summary $\left({ }^{* *}\right)$; variances are significantly different.

I. Drug at $2.5 \mathrm{nM}$ concentration on HUVEC cell caused the reduction of calcium waves and frequencies after adding drug 30 seconds later; showed with error bars and connecting line; unpaired $t$-test had done, $\mathrm{P}(<0.0001), \mathrm{P}$ value summary $(* * *)$, means are significantly different $(\mathrm{P}<0.05)$ and difference between means $(0.003404 \pm 0.0007989), 95 \%$ confidence interval $(0.001838$ to $0.004969)$ and R squared (0.1242), F-test (P value $<0.0001)$, P value summary $\left.{ }^{* * *}\right)$; variances are significantly different.

J. Drug at $1.5 \mathrm{nM}$ concentration on HUVEC cell had taken longer time of duration to reduce rate of decay of calcium waves and frequencies at a prescribed dose and after 20 seconds the calcium concentration on the cell was decreased rapidly. Unpaired t-test had done, $\mathrm{P}$ value $(<0.0001), \mathrm{P}$ value summary $(* * *)$, means are significantly different $(\mathrm{P}<0.05)$ and difference between means(0.01517 \pm 0.003207$), 95 \%$ confidence interval $(0.008880$ to 0.02145$)$ and $R$ squared $(0.1487)$, F-test $(P$ value $<0.0001), P$ value summary $(* * *)$; variances are significantly different.

K. HUVEC control group Vs drug applied in different concentration in terms of Fluorescence intensity vs time(seconds) graph; it represented by the one way ANOVA method (one-way analysis of variance), $\mathrm{P}<0.0001, \mathrm{P}$ value summary(***), $\mathrm{R}$ squared 0.7220 , means are significantly different $(\mathrm{P}<0.05)$. Bartlett's statistics corrected 782.4 and $\mathrm{P}$ value $<0.0001$, $\mathrm{P}$ value summary $(* * *)$ and the variances differ significantly $(\mathrm{p}<0.05)$.

L. HUVEC control group Vs drug applied in different concentration by using relative fluorescent unit $(\mathrm{F}(\mathrm{t}) / \mathrm{F}(0))$ values which were calculated for each cell; it represented by the one way ANOVA method (one-way analysis of variance), $\mathrm{P}$ value $<0.0095$, P value summary $\left({ }^{* *}\right)$, R squared0.04368, means are significantly different $(\mathrm{P}<0.05)$. Bartlett's statistics corrected 652.9 and $P$ value $<0.0001, P$ value summary $\left({ }^{* *}\right)$ and the variances differ significantly $(\mathrm{p}<0.05)$. 

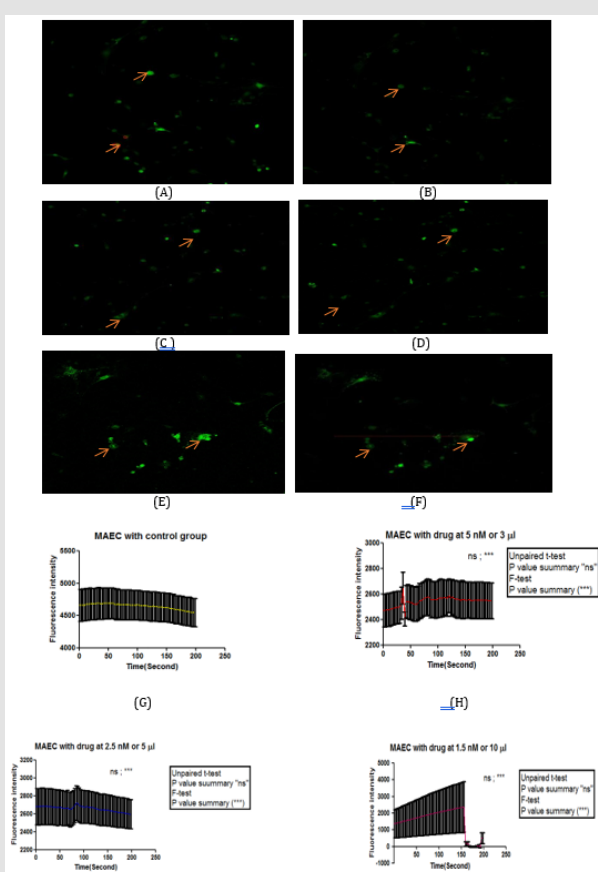

(H)

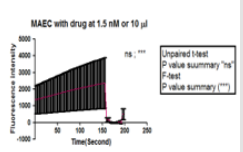

(I)

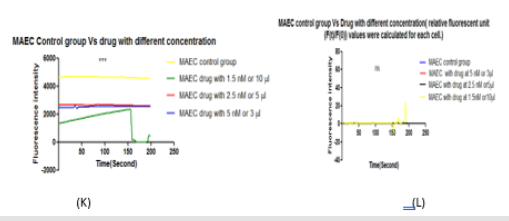

Figure 4: The effect of xanthohumol on suppression the frequency of MAEC was examined. MAEC cell was treated with xanthohumol within different concentrations (1.5nM to $5 \mathrm{nM})$. On treatment with xanthohumol, MAEC cell line showed fluorescence intensity reduction mostly decreased at $1.5 \mathrm{nM}(10 \mu \mathrm{l}$ concentration).

A. Represents the MAEC cell before adding drug;

B. Represents the drug after adding drug at $5 \mathrm{nM}$ concentration;

C. Before adding drug;

D. Image in the confocal microscope at $2.5 \mathrm{nM}$ concentration of the drug;

E. Represents the MAEC cell before adding drug;

F. The drug after adding drug at $1.5 \mathrm{nM}$ concentration for $10 \mu \mathrm{l}$ volume;

G. MAEC control group without drug at constant rate, graph showed by using PRISM software; showed with error bars and connecting line.

H. Drug at $5 \mathrm{nM}$ concentration on MAEC cell showed upward increase calcium waves and frequencies after 30 seconds later in the graph; showed with error bars and connecting line; unpaired t-test had done, $\mathrm{P}$ value(0.5834), $\mathrm{P}$ value summary (ns) and means are not significantly different $(\mathrm{P}<0.05)$, difference between means $(-0.0009885 \pm 0.002535), 95 \%$ confidence interval -0.004512 to 0.002535 , and $\mathrm{R}$ squared $(0.002357)$, F-test ( $\mathrm{P}$ value $<0.0001)$, $\mathrm{P}$ value summary $(* * *)$; variances are significantly different.

I. Drug at $2.5 \mathrm{nM}$ concentration on MAEC cell caused the slightly reduction of calcium waves and frequencies after adding drug and 80 seconds later slowly it decreased the calcium wave in the MAEC cell. showed with error bars and connecting line; unpaired t-test had done, $\mathrm{P}$ value (0.8075), $\mathrm{P}$ value summary (ns), means are not significantly different $(\mathrm{P}<0.05)$ and difference between means $(0.00008863 \pm 0.0003630), 95 \%$ confidence interval (-0.0006229 to 0.0008001$)$, and R squared (0.0004655), F-test (P value $<0.0001)$, $\mathrm{P}$ value summary $(* * *)$; variances are significantly different.

J. Drug at $1.5 \mathrm{nM}$ concentration on MAEC cell had taken longer time of duration to reduce rate of decay of calcium waves and frequencies at a prescribed dose and after 150 seconds the calcium concentration on the cell was decreased rapidly, but until then the calcium waves and frequencies assume that it was increasing slowly because of the temperature fluctuation, and it happened for that particular time. Unpaired t-test had done, $\mathrm{P}$ value $(0.4606), \mathrm{P}$ value summary (ns), means are not significantly different $(\mathrm{P}<0.05)$ and difference between means $(-0.3008 \pm 0.4064), 95 \%$ confidence interval $(-1.097$ to 0.4958$)$ and $\mathrm{R}$ squared $(0.004261)$, F-test (P value $<0.0001)$, P value summary $(* * *)$; variances are significantly different.

K. MAEC control group Vs drug applied in different concentration in terms of Fluorescence intensity vs time(seconds) graph; it represented by the one way ANOVA method (one-way analysis of variance), P value $<0.0001, \mathrm{P}$ value summary(***), $\mathrm{R}$ squared 0.8938 , means are significantly different $(\mathrm{P}<0.05)$. Bartlett's statistics corrected 862.5 and $\mathrm{P}$ value $<0.0001, \mathrm{P}$ value summary $\left.{ }^{* * *}\right)$ and the variances differ significantly $(p<0.05)$.

L. MAEC control group Vs drug applied in different concentration by using relative fluorescent unit $(\mathrm{F}(\mathrm{t}) / \mathrm{F}(0))$ values which were calculated for each cell; it represented by the one way ANOVA method (one-way analysis of variance), P-value0.6508, $\mathrm{P}$-value summary(ns), R squared 0.006365 , means are not significantly different $(\mathrm{P}<0.05)$. Bartlett's statistics corrected 2242 and $\mathrm{P}<0.0001, \mathrm{P}$ value summary $\left({ }^{* * *}\right)$ and the variances differ significantly $(\mathrm{p}<0.05)$. 


\section{Discussion}

Flavonoids are the most abundant polyphenols in the diet and several reports have shown the preventive actions. Xanthohumol is among the chemo-preventive natural compounds. Xanthohumol is a prenylated flavonoid of the chalcone type, found in the lupulin glands of the hop cones. In this study represent a promising role for xanthohumol as a cardiac protective agent. In vitro, in our experiment and others have shown that XN negatively interferes with endothelial cell growth, migration, invasion, and the ability to form a network of tubular-like structures. In this work, the the ability of XN didn't show any specific inhibition of endothelial cell functions on MAEC but reduces the frequency of spontaneously occurring calcium sparks and calcium waves in control HUVEC and in control MAEC cell's one concentration of drug applied group and Xanthohumol with different concentrations to reduce the rate of relaxation of electrically triggered calcium transients. Functioning as a signaling molecules Calcium ions $\left(\mathrm{Ca}^{2+}\right)$, are recognized to play a vital role in the control of biological processes, such as- metabolism, proliferation, secretion. Many cellular activities carried out in cytosolic compartments are driven in a $\mathrm{Ca}^{2+}$-dependent manner. Therefore, HUVEC and MAEC cell possess effective mechanisms for the regulation of cytoplasmic ([Ca $\left.{ }^{2+}\right]$ cyt) concentrations $[9,15]$. The $\mathrm{Ca}^{2+}$-regulating factors remain active and is able to produce highly organized $\mathrm{Ca}^{2+}$ signals including intracellular $\mathrm{Ca}^{2+}$ oscillations and moreover intercellular $\mathrm{Ca}^{2+}$ waves between adjacent cells [8]. Since $\mathrm{Ca}^{2+}$ regulates the cell cycle at several stages, $\mathrm{Ca}^{2+}$ signaling is importantly involved in cell-fate determination (quiescent state, proliferation or cell death). Some Mitogenic compounds such as platelet-derived growth factor, vasopressin, prostaglandin, EGF (Endothelial Growth Factor) evoke $\mathrm{Ca}^{2+}$ transients. Cells grown on $20 \mathrm{~mm}$ glass bottom cell culture dishes were loaded with the cell indicator dye. Fluo-4AM was used for monitoring changes in ([Ca $\left.\left.{ }^{2+}\right] c y t\right)$ diluted in cell culture media for $20 \mathrm{~min}$ at room temperature. We used an inverted confocal microscope (LSM880 model) integrated to a workstation to examine changes in $\left[\mathrm{Ca}^{2+}\right]$ cyt [15]. The following excitation wavelengths were used to illuminate the $\mathrm{Ca}^{2+}$ indicators: $488 \mathrm{~nm}$ for Fluo-4. At the confocal microscope, recordings were performed at $37^{\circ} \mathrm{C}$ using temperature control (37-2 digital), and a Heating Stage (LSM880 model, ZEISS,Germany) [15].

Xanthohumol is an important mediator of the anti-oxidant effects in human endothelial cells. Firstly, confirmed the ability of Xanthohumol to decrease HUVEC but not significantly to MAEC endothelial cell functions in vitro. Different Xanthohumol doses were used and time points to decrease endothelial cell migration, invasion and tube formation with reducing cell proliferation or viability mainly on HUVEC. A number of prenylated chalcones like xanthohumol was active at low concentrations, but not on normal tissue. But in our study, introduced the Xanthohumol's effect on the endothelial cell and through which can introduce the effect of the drug in the intracellular calcium concentration. In addition, further give us the route of drug's action on the cardiovascular protection by analyzing the endothelial cell function. The effect of xanthohumol was tested on two cell types derived from mouse aortic endothelial cells (MAEC) and human umbilical vein endothelial cells (HUVECs) and were selected because they have retained many morphologic and biochemical characteristics of their mammary origin. In found that $\mathrm{Ca}^{+2}$ Sparks and Waves Are Suppressed by Xanthohumol on HUVEC but not significantly on MAEC. The explored effects of exposures of xanthohumol on generation of $\mathrm{Ca}^{+2}$ sparks and waves in HUVEC and MAEC cells [8]. In control cells that had a high baseline spontaneous $\mathrm{Ca}^{+2}$ spark frequency, noticed that acute application of 1.5 to $5 \mathrm{nM}$ xanthohumol consistently reduced the spark frequency within 3minutes on HUVEC (figure 3). The lower frequencies of spontaneously triggered Calcium sparks and waves in both cell. Cells were subjected to longer periods of irregular $\mathrm{Ca}^{+2}$ oscillations that led to loss of excitability and were not further considered. In set of experiments, measured the frequency of spontaneously generated $\mathrm{Ca}^{+2}$ sparks in HUVEC and MAEC cells incubated for 30 minutes in control solutions and after adding the Xanthohumol in different concentrations [15].

In both cell types, spontaneously developed $\mathrm{Ca}^{+2}$ oscillations or sparks were short. Dose-Dependent Effects of Xanthohumol. Examined the concentration-dependent effects of xanthohumol on amplitude and rate of decay of Calcium transients at $37^{\circ} \mathrm{C}$. Each cell types were exposed to one concentration of xanthohumol for a period of 1 to 3 minutes to prevent progressive effects resulting from intracellular accumulations of Xanthohumol [8].

The effects of xanthohumol on $\mathrm{Ca}^{+2}$ signaling parameters using concentrations ranging between $1.5 \mathrm{nM}$ and $5 \mathrm{nM}$. The experiments were carried out under the conditions both at room temperature and $37^{\circ} \mathrm{C} . \mathrm{Ca}^{+2}$ current were suppressed by xanthohumol when the concentration of the drug applied at $1.5 \mathrm{nM}$. In sharp contrast at 37 ${ }^{\circ} \mathrm{C}$, $5 \mathrm{nM}$ xanthohumol concentrations slightly increased the $\mathrm{Ca}^{+2}$

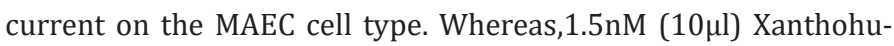
mol at room temperature, which had decreased on Calcium current on both cell types, and significantly suppressed $\mathrm{Ca}^{+2}$ transients at room temperatures $\left(25^{\circ} \mathrm{C}\right)$, xanthohumol also slowed the kinetics of relaxation of $\mathrm{Ca}^{+2}$ transients, as it suppressed its peak, at concentrations $1.5 \mathrm{nM}$. The strong suppressive effects of xanthohumol in reducing the peak and slowing the decay of the Calcium transients were significantly reduced at $37^{\circ} \mathrm{C}$, such that only concentrations of $1.5 \mathrm{nM}$ had significant effects on rate of their decay $[5,8]$. The major finding of this study is that Xanthohumol is an antioxidant member of chalcone family, at nanomolar concentrations, effectively suppresses the frequency of spontaneously occurring $\mathrm{Ca}^{+2}$ sparks and $\mathrm{Ca}^{+2}$ transients, in HUVEC and MAEC cells because intracellular Calcium signaling is associated with a host of cardiac pathologies, including arrhythmia, coronary artery disease, high blood pressure and atherosclerosis [8].

It is likely that xanthohumol might have a therapeutic potential in treatment of arrhythmia. The reducing spark frequencies men- 
tioned in cells with different concentration of drugs calcium might change the cells susceptible to triggered arrhythmia, and heart failure, remarkable increases in cytosolic calcium which reported by [20]. Xanthohumol increased $\mathrm{Ca}^{2+}$ swing in both cell lines. Results based on pharmacological point of view to an involvement of the AMPK (5' adenosine monophosphate-activated protein kinase) activation in Xanthohumol-evoked $\mathrm{Ca}^{2+}$ responses [3]. Finally, Xanthohumol decreased cell viability and induced oxidative stress.

\section{Conclusion}

In this study findings and suggests that a treatment of endothelial cells with Xanthohumol which leads to increased AMPK phosphorylation and activity. The frequency of spontaneously occurring calcium sparks and calcium waves in control cell and in cells reduced the rate of relaxation of Xanthohumol triggered calcium transients and showed the highest inhibitory activity on the HUVEC when Xanthohumol concentration was at 1.5 to $5 \mathrm{nM}$. These characteristics were specific to Xanthohumol among the flavonoids. Current study provided evidence that Xanthohumol also suppresses the calcium content of the cytoplasm and its rate of recirculation. Author decide to start with future studies to establish functional studies to confirm that AMPK mediates Xanthohumol as an antihypertensive agent and the mechanisms will show that Xanthohumol-induced AMPK activation reduces nitric oxide levels in endothelial cells. In the futures study, it's is highly needed to pharmacological and knockout approaches to assure and confirm Xanthohumol decreases eNOS phosphorylation. In addition, it will be very promising to research a new potential method that will explore the bcl-2 family expression changes in the extracted protein.

\section{Acknowledgement}

The authors gratefully acknowledge to Prof. Dr. Xin Ma, Dr. Li Geng and China Scholarship Council (CSC), Beijing, China (CSC No. 2017GBJ009657) and also extend our sincere gratitude to the staff and students of the research center of Wuxi School of Medicine, Jiangnan University, Wuxi, China, for supporting this research.

\section{References}

1. Che J, Bing Liang, Yuan Zhang, Yi Wang, Jianyu Tang, et al. (2017) Kaempferol alleviates ox-LDL-induced apoptosis by up-regulation of autophagy via inhibiting PI3K/Akt/mTOR pathway in human endothelial cells. Cardiovascular Pathology 31: 57-62.

2. Hirata H, Takazumi K, Segawa S, Okada Y, Kobayashi N, et al. (2012) Xanthohumol, a prenylated chalcone from Humulus lupulus L, inhibits cholesteryl ester transfer protein. Food chemistry 134(3): 1432-1437.

3. Gallo C, Dallaglio K, Bassani B, Rossi T, Rossello A, et al. (2016) Hop derived flavonoid xanthohumol inhibits endothelial cell functions via AMPK activation. Oncotarget 7(37): 59917-59931.

4. Melzig MF, Loose R (1998) Inhibition of Lipopolysaccharide (LPS)lnduced Endothelial Cytotoxicity by Selected Flavonoids. Planta medica 64(5): 397-399.
5. Negrão R, João Incio, Rui Lopes, Isabel Azevedo, Raquel Soares (2007) Evidence for the effects of xanthohumol in disrupting angiogenic, but not stable vessels. International journal of biomedical science: IJBS 3(4): 279-286.

6. Xin G, Zeliang Wei, Chengjie Ji, Huajie Zheng, Jun Gu, et al. (2017) Xanthohumol isolated from Humulus lupulus prevents thrombosis without increased bleeding risk by inhibiting platelet activation and mtDNA release. Free Radical Biology and Medicine 108: 247-257.

7. Vanhoecke B, Derycke L, Van Marck V, Depypere H, De Keukeleire D, et al. (2005) Antiinvasive effect of xanthohumol, a prenylated chalcone present in hops (Humulus lupulus L.) and beer. International Journal of Cancer 117(6): 889-895.

8. Arnaiz Cot JJ, Cleemann L, Morad M (2017) Xanthohumol modulates calcium signaling in rat ventricular myocytes: Possible Antiarrhythmic properties. Journal of Pharmacology and Experimental Therapeutics $360(1): 239-248$.

9. Kong Q, Feng Chen, Xi Wang, Jing Li (2011) Optimization of Conditions for Enzymatic Production of ACE Inhibitory Peptides from Collagen. Food \& Bioprocess Technology 4(7): 1205-1211.

10. Jiang CH, Tao Li Sun, Da Xiong Xiang, Shan Shan Wei, Wen Qun Li (2018) Anticancer activity and mechanism of xanthohumol: a prenylated flavonoid from hops (Humulus lupulus L.). Frontiers in pharmacology 9: 530 .

11. He D, Pan Q, Chen Z, Sun C, Zhang P, et al. (2017) Treatment of hypertension by increasing impaired endothelial TRPV4-KCa2. 3 interaction. EMBO molecular medicine 9(11): 1491-1503.

12. Ni CW, Sandeep Kumar, Casey J Ankeny, Hanjoong Jo (2014) Development of immortalized mouse aortic endothelial cell lines. Vascular cell 6: 7.

13. Van Beijnum JR, Rousch M, Castermans K, van der Linden E, Griffioen AW (2008) Isolation of endothelial cells from fresh tissues. Nature protocols 3(6): 1085-1091.

14. Jeon D, Kim SJ, Kim HS (2017) Anti-inflammatory evaluation of the methanolic extract of Taraxacum officinale in LPS-stimulated human umbilical vein endothelial cells. BMC complementary and alternative medicine 17(1): 508.

15. Nazıroğlu M, Blum W, Jósvay K, Çiğ B, Henzi T, et al. (2018) Menthol evokes $\mathrm{Ca}^{2+}$ signals and induces oxidative stress independently of the presence of TRPM8 (menthol) receptor in cancer cells. Redox biology 14: 439-449.

16. Choy KW, Mustafa MR, Lau YS, Liu J, Murugan D, et al. (2016) Paeonol protects against endoplasmic reticulum stress-induced endothelial dysfunction via AMPK/PPAR $\delta$ signaling pathway. Biochemical Pharmacology 116: 51-62.

17. Qiu MK, Wang SC, Tang Y, Pan C, Wang Y, et al. (2017) Tim-3 inhibits lowdensity lipoprotein-induced atherogenic responses in human umbilical vein endothelial cells. Oncotarget 8(37): 61001-61010.

18. De Andrade CM, Sa MF Toloi MR (2012) Effects of phytoestrogens derived from soybean on expression of adhesion molecules on HUVEC. Climacteric 15(2): 186-194.

19. He S, Fanghua Wang, Zhenxiang Ning, Bo Yang, Yonghua Wang (2015) Autolysis of anchovy (Engraulis japonicus) protein: Evaluation of antioxidant properties and nutritional quality of resulting hydrolysates. Journal of Aquatic Food Product Technology 24(5): 417-428.

20. Waadt R, Krebs M, Kudla J, Schumacher K (2017) Multiparameter imaging of calcium and abscisic acid and high-resolution quantitative calcium measurements using R-GEC01-mTurquoise in Arabidopsis. New Phytologist 216(1): 303-320. 


\section{ISSN: 2574-1241}

DOI: $10.26717 /$ BJSTR.2019.23.003860

Md. Mahfujul Haque Haidary. Biomed J Sci \& Tech Res

CC) This work is licensed under Creative Submission Link: https://biomedres.us/submit-manuscript.php

$\begin{array}{ll}\text { BIOMEDICAL } & \text { Assets of Publishing with us } \\ \text { RESEARCHES } & \text { - Global archiving of articles } \\ \text { - Immediate, unrestricted online access }\end{array}$

